\title{
Martin Kristiansson
}

Centrum för de samhällsvetenskapliga ämnenas didaktik

Karlstads Universitet

E-post: martin.kristiansson@kau.se

\section{Underordnat, undanskymt och otydligt - om samhällskunskapsämnets relationsproblem inom SO-gruppen på svenskt mellanstadium}

\section{Sammandrag}

I artikeln diskuteras en lärarstudie om vad som utmärker samhällskunskapsämnet på svenskt mellanstadium. Det sker mot bakgrund av en skandinavisk ämnesdidaktisk diskussion om ämnets tydlighet med fokus riktad mot svenska förhållanden. Här har ämnet beskrivits som otydligt i läroplans- och läroboksforskning medan det framträder som mer tydligt i lärarforskning. Denna lärarforskning har dock oftast studerat grundskolans högstadium och gymnasium. Studier på mellanstadiet saknas och min studie visar, till skillnad från dessa studier, att ämnet är otydligt när lärarna talar om det. Det är ett stadie som också skiljer sig från högstadiets och gymnasiets ämnescentrerade ämneslärarkultur genom att det är mer elevcentrerat och klasslärarbundet med högre grad av ämnesintegration. Artikeln fokuserar därför samhällskunskapsämnets relationer till övriga samhällsorienterande (SO) ämnen - geografi, historia och religionskunskap - och vad det innebär för ämnets otydlighet. Genom intervjuer med lärare om deras SO-undervisning och samhällskunskapsämnets del i den, illustrerat med hjälp av begreppen "ämnesmarkörer", "ämnesväxlingar" och "ämnesöverlappningar", framträder ämnet som underordnat och undanskymt $i$ relation till särskilt geografi och historia. De har en dominerande position inom gruppen och bidrar till att samhällskunskapsämnet förblir otydligt. I artikelns konklusion och diskussion argumenteras för betydelsen av en rekonstruktion av relationerna inom gruppen, inte endast för att göra samhällskunskapsämnet tydligare, utan för att också övriga ämnen skall ge ett starkare bidrag till elevers lärande om samhället och dess frågor både som enskilda ämnen och tillsammans.

Nyckelord: samhällskunskap, samhällsorienterande ämnen, ämnesmarkörer, ämnesväxlingar, ämnesöverlappningar

\section{Abstract}

This article reports on a practice-related study of the characteristic features of the civics subject in Swedish upper primary education. The discussion takes 
place against the background of a Scandinavian subject-specific pedagogical debate on the lack of clarity in the civics subject in relation to the other social studies subjects. In Sweden, curriculum and textbook research has pointed out that civics seems to have a vague and unspecified role in primary education, while it seems to have a more prominent role in practice-related research. However, the latter research has often focused on lower and upper secondary education, and so far there have been no studies of the role of civics in primary education. In contrast to the studies of civics in secondary education, my study shows that civics in primary education emerges as very obscure in teachers' talk about it. At this stage of education, civics is not as subject-centred as it is in the subject-teaching culture of secondary education, but rather a pupil-centred subject with a high degree of integration with other subjects. The article has a focus on civics in relation to the other social studies subjects (SO), namely geography, history and religious studies, and on how the interrelations affect the perception of civics. The study is based on interviews with teachers on their SO teaching and the role of civics with the help of the concepts of "subject marker", "subject-switching", and "subject-overlapping". The result of the analysis is that civics emerges as a subordinated and inconspicuous subject in relation to geography and history, in particular. These two subjects have a dominant position in the subject cluster and contribute to relegating civics to a vague and unclear backseat. In conclusion, the article argues for the need of reconstructing the interrelations in the subject cluster, not only for the sake of clarifying the role and content of civics, but also to ensure that the other subjects can also contribute more to pupils' learning about community and citizenship issues, as separate subjects and together.

Keywords: civics, social studies subjects, subjects, subject marker, subjectswitching, subject-overlapping

\section{Inledning}

Vad som utmärker olika skolämnen och dess syften har ofta diskuterats inom ämnesdidaktisk forskning. Inte sällan har diskussionen handlat om tydligheten hos ämnena. Tydliga ämnen med tydliga syften har i regel setts som mindre problematiska än otydliga ämnen med otydliga syften och på så vis också som mindre ifrågasatta som skolämnen.

Samhällskunskapsämnet (motsvarande samfunnskunnskap) i Skandinavien har måhända varit särskilt besökt av diskussioner kring dess tydlighet. Ämnet är relativt ungt. Det var starkt influerat av politiska förhandlingar och kompromisser om dess syfte och innehåll vid dess införande. Dess relation till det omgivande samhället och till vetenskapliga discipliner har ofta framhävts som mångbottnad och svårgripbar (se exempelvis Børhaug, Hunnes \& Samnøy, 
2015; Christensen, 2011, 2015; Koritzinsky, 2014; Olsson, 2016). Allt detta inverkar på diskussionerna om ämnets tydlighet.

Olsson (2016) ägnar en stor del av forskningsläget i sin avhandling åt frågan där han visar hur tydligheten i samhällskunskapsämnet i en svensk kontext varierar beroende av "vilket" ämne som studerats. Läroplans- och läroboksforskare har ofta betonat ämnets otydlighet, medan bilden blir en annan när lärarstudier beaktas, menar han. Då framträder ämnet som mer tydligt. Det har ett etablerat innehåll i form av olika kunskapsområden som återkommer och följer på varandra genom ett momentindelat undervisningsupplägg (Olsson, 2016). Det är emellertid en tydlighet som rör högstadie- och gymnasieämnet (Olsson, 2016). Aktuella studier i Sverige om vad som utmärker ämnet i de tidigare årskurserna saknas. Den övergripande frågan som skall diskuteras i denna artikel är: Vad utmärker samhällskunskapsämnet som mellanstadieämne när lärare som undervisar i det talar om det?

Det är en fråga som ingår i en annan kontext än studier gjorda på högstadiet och gymnasiet. Högre upp i skolsystemet dominerar en ämnesgrundad organisering av undervisningen, ofta understödd av en stark ämneslärarkultur. Längre ned i systemet är det vanligare att enskilda ämnen tonas ned och att undervisningen organiseras mer utifrån ett elevperspektiv med inslag av ämnesintegrerad undervisning och understödd av en klasslärarkultur (Imsen, 1999). För det mesta har således ämnet en mindre framträdande roll ju längre ner i skolsystemet man kommer, även om skillnaderna inte skall överdrivas. I Sverige och i många andra länder är grundstrukturen styrd av skolämnen, vilket bland annat kommer till uttryck i den timplan uppdelad i ämnen som gäller för svensk grundskola (Skollagen 2010:800).

Likväl är det viktigt att beakta skillnader i kontext när skolämnen skall studeras på olika stadier och i olika skolformer. Merparten av de lärarstudier på högstadiet och gymnasiet som Olsson tar upp, har en gemensam ansats i att samhällskunskapsämnet studeras som ett enskilt ämne utan kopplingar till andra ämnen. Det är en ansats som är rimlig i en kontext där ämnesuppdelning dominerar, även om det inom det ämnesdidaktiska fältet blivit allt vanligare att peka på vikten av komparativa ämnesstudier för att nå en mer nyanserad och skarp bild av ämnen och undervisningen i dem (se exempelvis Krogh \& Nielsen, 2011, 2012). Studeras ämnen längre ned i skolsystemet är ansatsen mer problematisk givet den relativa nedtoningen av ämnet. Då kan det vara fruktbart att studera ett ämne som samhällskunskap, inte endast som ett enskilt ämne, utan också i jämförelse med andra ämnen. Givet att ämnet också kan verka inom ämnesintegrerade sammanhang finns det anledning att också studera dess relationer till andra ämnen. Detta har inte skett så ofta i de samhällsvetenskapliga ämnenas didaktik (Christensen \& Hobel, 2014; Schüllerqvist, 2012) som är det område inom vilket jag har min forskningstillhörighet. Den annorlunda kontext som råder för ämnen på mellanstadiet motiverar således en kombination av dessa ansatser för att bli allsidigt belysta. Därför har jag studerat 
samhällskunskapsämnet som lärarämne på mellanstadiet som ett enskilt ämne, men också jämfört det med dess "systerämnen" inom den samhällsorienterande (SO) gruppen (motsvarande norskt samfunnsfag) - geografi, historia och religionskunskap - och dess relationer till dem.

\section{Syfte och preciserade frågeställningar}

Jag har redogjort för resultat från min studie i en tidigare artikel när det gäller den enskilda och jämförande ansatsen (Kristiansson, 2014). Till skillnad från Olssons beskrivning av lärarstudierna på högstadiet och gymnasiet, framträdde ämnet som tämligen otydligt hos mellanstadielärarna. Visserligen syntes också här etablerade och återkommande kunskapsområden gemensamma för lärarna. Men de framträdde som mer otydliga inåt och mer osammanhängande visavi varandra. Vidare saknades det momentindelade undervisningsupplägg som utmärkte ämnet i Olssons refererade studier. Dessutom angavs ämnet vara svårgripbart när dess yttre gränser beaktades. Vad lärarna gav uttryck för när de talade om samhällskunskap som enskilt ämne kan sammanfattas med att de upplevde det som stort, gränslöst, osammanhängande och föränderligt (Kristiansson, 2014). Dessa är emellertid inte kännetecken som av nödvändighet följer av att ämnet verkar inom den mindre ämnesstyrda kontext som diskuterats ovan. I så fall skulle också de andra SO-ämnena anta liknande kännetecken, och det gjorde de inte.

Särskilt geografi och historia framträdde som betydligt tydligare i jämförelse, en tydlighet som också verkade påverka ämnenas positioner och roller inom SOgruppen. Tydligheten hos geografi och historia tycks ha gett dem en mer central position visavi samhällskunskap och religionskunskap som också verkar påverka rollerna mellan dem när de interagerar inom gruppen. Denna relationella aspekt av vad som utmärker samhällskunskapsämnet när det verkar inom SO-gruppen tillsammans med de andra SO-ämnena antyddes endast i artikeln. Vad lärarna angav som ytterligare ett utmärkande drag var nämligen att ämnet "gick in" i de andra SO-ämnena, något som till och med beskrevs som dess "röda tråd" (Kristiansson, 2014 s. 218). När den övergripande frågan om samhällskunskapsämnets kännetecken skall belysas i denna artikel betonas därför den relationella ansatsen genom att framhäva samhällskunskapsämnets interaktioner med de andra SO-ämnena. I dessa interaktioner intar vanligtvis samhällskunskap en underordnad roll som bidrar till att en undanskymd position i gruppen och otydligheten som eget ämne vidmakthålls. Syftet med artikeln är att visa hur detta kommer till uttryck i mellanstadielärares tal om samhällskunskapsämnet och undervisningen i det genom illustrerande exempel på ämnets interaktion med de andra SO-ämnena. De mer preciserade frågor som legat bakom identifieringen av de mönster som dessa illustrationer skall visa är: 
- På vilka sätt interagerar samhällskunskapsämnet med de andra SOämnena?

- Vilka roller intar samhällskunskapsämnet i interaktionerna?

o Hur inverkar rolltagandet på samhällskunskapsämnets position inom SO-gruppen?

o Hur inverkar rolltagandet på samhällskunskapsämnets kännetecken som eget ämne inom SO-gruppen?

Behandlingen av dessa frågor utgör ett nytt bidrag till den samhällskunskapsdidaktiska diskussionen om ämnets tydlighet i Sverige genom att en lärarstudie som rör mellanstadiet läggs till de studier som diskuterat tydligheten hos ämnet på högstadiet och gymnasiet. I vidare mening utgör behandlingen ett bidrag till ämnesdidaktisk forskning om hur ett ämne kan studeras genom att kombinera studiet av ett enskilt ämne med en jämförande och relationell ansats.

\section{Disposition}

Nedan börjar jag med att ge en kort bakgrund till och beskrivning av ramarna för den studie som artikelns resultat vilar på. Därefter diskuteras frågan om samhällskunskapsämnets tydlighet med fokus på svensk lärarforskning i syfte att visa i vilket sammanhang bidraget från min studie skall ses mer precist. Sedan följer en beskrivning av de begrepp som skapats och använts för att analysera samhällskunskapsämnets interaktion med de andra SO-ämnena i studien följt av en beskrivning av studiens metod. Mot denna bakgrund presenteras studiens resultat och artikeln avslutas med en diskussion om resultatens betydelse för samhällskunskapsdidaktisk och ämnesdidaktisk forskning nu och framöver.

\section{Bakgrund}

År 2010 fick "Centrum för de samhällsvetenskapliga ämnenas didaktik” (CSD) i uppdrag av lärarutbildningen vid Karlstads universitet att forska om SO-ämnena på mellanstadiet. Syftet var att stärka den vetenskapliga grunden för undervisningen om detta vid lärarutbildningen, men också att bidra till ny forskning på området mer allmänt. I det forskningsprogram som antogs för att ta sig an uppdraget, diskuterades såväl forskningsläget som trender i samhället i syfte att mejsla fram projektets huvudsakliga vägval och inriktning. Samtliga SO-ämnen skulle representeras och fokus skulle ligga på lärarstudier utifrån begreppsbildning och bedömning (Schüllerqvist, 2010).

Vid tidpunkten var ämnesdidaktisk lärarforskning relativt eftersatt inom de samhällsvetenskapliga ämnena (Schüllerqvist, 2009) samtidigt som frågor om bedömning diskuterades flitigt såväl i samhället som inom forskningen. Utbildningssystem världen över utkrävdes ansvar utifrån olika rumsliga och tidsliga resultatjämförelser (Linn, 2000; Sjøberg, 2014). I båda avseenden visade Sverige sjunkande resultat (Skolverket, 2010, 2013) och reformer genomfördes i 
ett uttalat syfte att vända trenden. Elevernas resultat skulle förbättras genom en utökad och mer preciserad stadieindelning, färre och tydligare mål, fler betygstillfällen och fler betygssteg. Som gemensam nämnare för dessa förändringar stod ett starkare fokus på ämneskunskaper (Prop. 2008/09:66; Prop. 2008/ 09:87). Samtidigt med dessa reformer växte bedömningsforskningen i Sverige för att skapa en vetenskaplig grund att hantera utmaningarna men också för att problematisera dess grundvalar (se exempelvis Forsberg \& Lindberg, 2010).

För SO-ämnena på mellanstadiet innebar reformerna att gemensamma skrivningar för gruppen som helhet togs bort samtidigt som formuleringar om ämnesspecifika förmågor, ett ämnesbundet centralt innehåll och tillika ämnesbundna kunskapskrav framhävdes i respektive ämne (Skolverket, 2011). Dessutom skulle lärarna sätta betyg i årskurs 6 baserat på de ämnesbundna kunskapskraven, en betygsättning som inte skett på över trettio år (Prop. 2008/09:66). Samtidigt saknades aktuell forskning om just SO-ämnena på mellanstadiet varpå såväl verksamma lärare som utbildning av framtida lärare saknade den vetenskapliga grund om området som betonades för professionen i den nya skollagen (Skollagen 2010:800). Det var en avsaknad av forskning som i sin tur saknade en vidare bas genom att forskning om de samhällsvetenskapliga ämnenas didaktik var svagt utvecklad i allmänhet. De få lärarstudier som hade gjorts i Sverige pekade mot att lärare saknade ett ämnesdidaktiskt språk och var i behov av ämnesdidaktiska begrepp för att kunna diskutera sin undervisning på en starkare grund (Schüllerqvist \& Osbeck, 2009). Detta utgångsläge medförde att programmet antog en induktiv och explorativ grundstrategi med begreppsbildande avsikter (Schüllerqvist, 2010). Jag anställdes i projektet för att studera lärares tal om samhällskunskapsämnet och undervisningen i det utifrån denna grundstrategin. Den bild av ämnet som enskilt ämne och i jämförelse med övriga ämnen i SO-gruppen som tagits upp ovan är således induktivt och explorativt frammejslad. Det framträder, som sagt, som ett otydligt ämne jämfört med sina systerämnen i SO-gruppen, men också jämfört med samhällskunskapsämnet som lärarämne på svenskt högstadium och på gymnasiet. Låt mig utveckla hur resultatet från min studie skall hanteras mer precist i den framförliggande artikeln med hänsyn till dessa lärarstudier.

\section{Tidigare forskning}

De lärarstudier som Olsson diskuterar är, likt hans egen studie, intensiva fallstudier utan anspråk på generaliseringar av vad som utmärker ämnet grundat på svenska samhällskunskapslärare som population. Likväl indikerar studierna att samhällskunskapsämnet har ett återkommande innehåll som satt sig och som Olsson till och med problematiserar i termer av ämnestraditioner (Olsson, 2016). Lärarna i dessa studier har beskrivit detta ämnesinnehåll oberoende av varandra, vilket stärker påståendet om en tydlighet internt i studierna, samtidigt som stu- 
dierna sinsemellan ger liknande beskrivningar och på så vis stärker påståendet externt. Olssons egna noggrant utförda inventering i hans första delstudie i avhandlingen ger samma grundbild (Olsson, 2016). Men att ett visst innehåll återkommer och har etablerats i termer av olika kunskapsområden som i sin tur äger liknande komponenter, behöver inte av nödvändighet innebära att samhällskunskapsämnet är tydligt, åtminstone inte helt och hållet. Vissa aspekter kan vara mer tydliga än andra.

För det första visar Olsson (2016) en större samstämmighet inom och mellan lärarstudierna gällande innehållet på kunskapsområdesnivå medan vad som ingår i de olika områdena varierar mer. För det andra är det en samstämmighet på aggregerad nivå utan mer grundliga analyser om vad som mer precist kännetecknar kunskapsområdena. För det tredje beskrivs såväl kunskapsområdena som dess undernivåer som relativt enkla uppräkningar, utan att det förs en diskussion om hur kunskapsområdena är relaterade till varandra och hur delarna inom respektive kunskapsområden är relaterade till varandra. Som jag ser det är ett ämnes identitet, kärna och tydlighet inte endast avhängig av att vissa områden med vissa underavdelningar återkommer och undervisas efter varandra. Frågor om hur dess olika områden mer nyanserat tar sig uttryck och hur de hänger ihop internt och i relation till varandra, är också relevant för att diskutera ett ämnes tydlighet. Hur följer undervisningen av de olika kunskapsområdena på varandra och vad kan förklara detta? Hur förhåller sig ett kunskapsområde till ett annat och en aspekt inom ett kunskapsområde till ett annat? Vad är det som gör att ämnets tvärvetenskapliga karaktär "till trots” ändå är tänkt att verka som ett eget skolämne? Och är inte lärarstudierna ett uttryck för en viss reduktion av denna tvärvetenskaplighet när kunskapsområden inom statsvetenskap dominerar följt av nationalekonomi? Varför syns exempelvis inte sociologi mer tydligt i ämnet och de frågor denna disciplin ställer om individer och samhället?

Frågor likt de ovan nämnda är inte grundligt behandlade i lärarstudierna varför det finns anledning att tala om ämnets relativa tydlighet i ett mer avgränsat ljus. Låter man dessa frågor styra läsningen av de studier Olsson refererar finns indikationer på ökad otydlighet hos ämnet. Vissa delar återkommer. Men vad som ingår i dem mer exakt, hur de hänger ihop, om de hänger ihop och varför de hänger ihop på ett visst sätt är inte alls lika klart. Odenstads (2011) studie av lärares prov visar exempelvis att ämnet ser olika ut beroende av kunskapsområden där kunskap om statsskick indikerar ett orienteringsämne, medan kunskap om ekonomi indikerar ett analysämne och rättsliga områden indikerar ett diskussionsämne. Då kan man fråga sig om inte alla dessa områden skulle kunna förstås såväl orienterings-, som analys- och diskussionsmässigt. Att olika ämnesbetoningar framträder på olika sätt beroende av olika kunskapsområden indikerar då att ämnet inte hänger ihop och tenderar att falla isär i olika delämnen. I Bernmark-Ottossons (2009) lärarstudie kan man se hur politik och ekonomi dominerar och att det ges uttryck för att dessa hänger ihop, men någon fördjupad beskrivning av hur detta ser ut framträder inte. Huvudintrycket är att 
ämnet framstår som reducerat och uppdelat i enlighet med Olssons (2016) egna beskrivning av studiens resultat, dess ansats till trots:

Ansatsen i studien (att beskriva en slags helhetsmässig föreställning om ämnet hos lärarna som här kallas ämnesdidaktiska strategi) är för övrigt sällsynt, även om syntetiseringen av lärarnas syn på mål, innehåll och metoder är svagt framskriven hos Bernmark-Ottosson och inte utmynnat i rubricerande begrepp. (s. 76)

Att syntetiseringen är svagt framskriven behöver inte bero på en svag insamling av data eller analys, utan kan lika gärna grunda sig i att den är "svagt” utvecklad av lärarna - eller otydlig i detta avseende. Likväl står det klart att svenska lärarstudier på högstadiet och gymnasiet framhäver ett tydligare ämne än det jag funnit när jag samtalat med mellanstadielärare om deras SO-undervisning och samhällskunskapsämnets del av den. Detta stämmer också med äldre lärarstudier som inkluderat lärare från hela grundskolan samt gymnasiet. Då blir bilden av ämnet mindre samstämmig med indikationer på en ökad otydlighet längre ner i skolåldern (Vernersson, 1999). Otydligheten hos samhällskunskapsämnet i min studie har jag diskuterat med hjälp av begreppet "ämnesmarkörer" som bildades i samband med genomförandet av den och som har relevans för illustrationen av ämnets relation till de andra SO-ämnena i artikelns resultatdel längre fram. Tillsammans med begreppen "ämnesväxlingar” och "ämnesöverlappningar” som också bildades i samband med studien, utgör "ämnesmarkörer" den begreppsliga ramen för illustrationen. Denna ram diskuteras nedan.

\section{Begreppslig inramning}

Begreppet ämnesmarkörer har likheter med Basil Bernsteins begrepp om svag och stark klassifikation (Sadovnik, 1995) men bildades induktivt utifrån tolkning av det lärarna gav uttryck för om SO- och samhällskunskapsundervisningen. Ämnesmarkörer gör ett ämne synligt som eget ämne och verkar på olika nivåer. På konkret nivå blir ämnet synligt genom att man nämner det vid namn, skriver upp det på tavlan och på schemat och har egna läroböcker, läxor och prov i det. Dessa markörer har jag gett prefixet etiketterande ämnesmarkörer. På en djupare nivå blir ett ämne också synligt om de äger principer som håller samman ämnet och skapar ordning i dess olika delar. Markörer av detta slag har jag benämnt strukturerande ämnesmarkörer. Det visade sig att samhällskunskapsämnets otydlighet kunde diskuteras utifrån att det saknade både etiketterande och strukturerande ämnesmarkörer. Geografi och historia, och till viss del religionskunskap, däremot, ägde båda typerna och detta påverkar samhällskunskapsämnets roll och position i relation till framförallt geografi och historia. Samhällskunskapsämnet tar en underordnad roll genom att fungera som, vad som inom forskning om ämnesintegration kallas "biämne" eller "hjälpämne" (Adler \& Flihan, 1997; Blanck, 2014; Klausen, 2011) åt dessa "huvudämnen". 
Däremot är relationen till religionskunskapsämnet mer likställd. $\AA$ andra sidan lever religionskunskap en undanskymd tillvaro i SO-gruppen genom att också detta ämnes ämnesmarkörer, likt samhällskunskapsämnets, är outvecklade (Kristiansson, 2014). Inget av ämnena dominerar det andra eftersom de är i princip lika svaga i SO-gruppen.

En närmare beskrivning och diskussion om hur den underordnade roll som mestadels präglar samhällskunskapsämnets relationer till de andra SO-ämnena tar sig uttryck, kommer att ske med hjälp av begreppen "ämnesväxlingar” och "ämnesöverlappningar". Likt "ämnesmarkörer" har även dessa begrepp beröringspunkter med redan etablerade begrepp i form av taxonomier som skapats för att belysa olika grad av ämnesintegration (Klein, 2010). Ämnesväxlingar och ämnesöverlappningar kan ses som begrepp som rör sig mellan multi- och interdisciplinär integration (Blanck, 2014) och med vars hjälp man kan belysa integrationens karaktär. Likt ämnesmarkörer har begreppen likafullt bildats induktivt utifrån tolkningar av intervjuerna med lärarna.

När en ämnesväxling sker mellan två eller flera ämnen, är det tydligt vad som utgör de ingående ämnenas specifika bidrag till ett för ämnena gemensamt undervisningsinnehåll. När ämnesöverlappningar sker är ämnenas bidrag inte tydliga. Båda dessa typer av relationer syns i samhällskunskapsämnets interaktioner med övriga SO-ämnen och kommer tillsammans med strukturerande ämnesmarkörer hjälpa oss att förstå varför ämnets roll och position ser ut som det gör och vad detta kan tänkas betyda för diskussionen om ämnets otydlighet. Figur 1 illustrerar den begreppsliga inramningen av dessa frågor (se också preciserade frågor i "Syfte och preciserade frågeställningar” ovan).

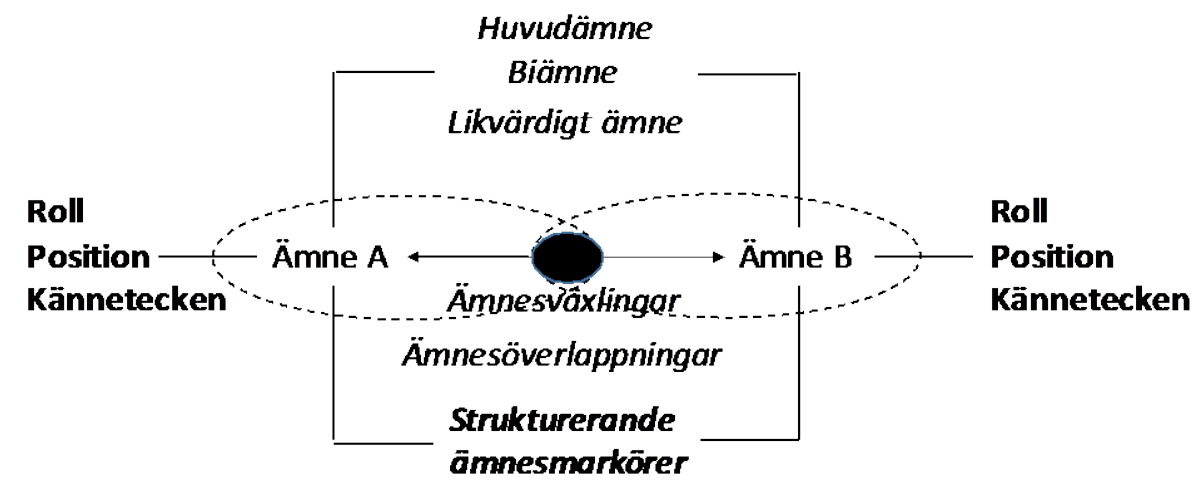

Figur 1: Begreppsram för analys av ämnesrelationer

Begreppsramen kan användas för studier av olika skolämnens relationer och skulle kunna utökas med interaktioner mellan fler än två ämnen. I denna artikel används ramen för att illustrera samhällskunskapsämnets interaktion med historia, geografi respektive religionskunskap vid SO-undervisning om ett gemensamt innehåll (se den svarta cirkeln i figuren). Interaktionen studeras i termer av ämnesväxlingar och ämnesöverlappningar utifrån den relativa styrkan i de ingående ämnenas strukturerande ämnesmarkörer. Starkare markörer styr i 
regel vilket ämne som intar rollen som huvudämne, respektive biämne, eller att de ingående ämnena intar en likvärdig roll när markörerna väger relativt lika. Denna relativa styrka hos respektive ämne i interaktionen indikerar också ämnenas relativa positioner inom, i mitt fall, SO-gruppen och utgör också en grund för vidmakthållanden av de kännetecken som ämnena äger som egna ämnen i gruppen. Vi skall snart se hur samhällskunskapsämnet intar rollen som underordnat biämne visavi historia och geografi som kan kopplas till de senare ämnenas relativt starka strukturerande ämnesmarkörer och hur detta också bidrar till samhällskunskapsämnets undanskymda position inom gruppen och otydlighet som eget ämne. Först skall jag emellertid redogöra för de metodiska överväganden och val som gjorts för att generera och tolka data om detta huvudmönster. Det är data som bygger på samtal med lärare om deras SO-undervisning och samhällskunskapsämnets del av den.

\section{Metod}

"Samtal" används på det sätt Kvale och Brinkmann (2009) gör när de beskriver forskningsintervjun som ett professionellt samtal där "kunskap konstrueras i interaktionen mellan intervjuaren och den intervjuade" som ett "utbyte av åsikter mellan två personer som samtalar om ett tema av ömsesidigt intresse” (s. 18). Temat för samtalen med lärarna var deras SO-undervisning och samhällskunskapsdelen i den så som det konstruerades i samtalen, och det är utifrån dessa konstruktioner som analysen av samhällskunskapsämnets relationer till de andra SO-ämnena i denna artikel har gjorts.

Mer precist består samtalen av inspelade och utskrivna individuella djupintervjuer med sju lärare - tre kvinnor och fyra män (deras namn i resultatdelen nedan är påhittade) - samt en inspelad och utskriven uppföljande gruppintervju med samma lärare. Gemensamt för lärarna är att de arbetar i samma kommun och undervisar i SO-ämnena, inbegripet samhällskunskap. I övrigt förekommer en variation bland dem vad avser utbildning, tid i yrket, typ av lärartjänst och typ av skolor de arbetar på, vilket bereder väg för ett erfarenhetsmässigt perspektivrikt samtal.

Huvudfrågan vid de individuella intervjuerna var: "När du undervisar i SO, vad brukar du undervisa om då?” Utifrån denna fråga användes en så kallad kognitiv karta som intervjuredskap (Khattri \& Miles, 1995). Intervjun drevs framåt genom att den intervjuade och intervjuaren, med hjälp av penna, post-it lappar och ett större pappersark, tillsammans konstruerade en karta över lärarnas SO-undervisning utifrån lärarnas uttalade erfarenheter av den. Fram träder en induktivt grundad bild av undervisningen som i takt med att intervjun fortskrider blir mer innehållsrik, relationsrik och nyanserad - en bild utifrån vilket ett särskilt intresse riktades mot att samtala om samhällskunskapsämnets del i undervisningen. 
Intervjuerna sammanfattades i text och gavs till lärarna som stöd för den efterföljande gruppintervjun. Under gruppintervjun fick var och en av lärarna beskriva sin SO-undervisning och samhällskunskapsämnets del i den, följt av frågor från deltagarna i syfte att nyansera och fördjupa beskrivningarna. Avslutningsvis fördes ett samtal om likheter och skillnader i beskrivningarna och vad de kunde bero på. I studien har alltså enskilda intervjuer kombinerats med en gruppintervju. Mer vanligt är att man väljer den ena eller andra intervjuformen (Bryman, 2011). Mervärdet att kombinera de båda intervjumetoderna ligger $\mathrm{i}$ att den information som kommit fram i de enskilda intervjuerna bearbetats till ett tydligare fokus på samhällskunskapens plats i SOundervisningen som lärarna fått ta del av och sedan tar med sig till gruppintervjun för att fördjupa och utveckla genom ömsesidigt erfarenhetsutbyte och reflektion med intervjuaren som moderator. Syftet har varit att konstruera en rikare och mer nyanserad information än om en av metoderna hade valts. Dessutom gynnar upplägget intervjuernas tillförlitlighet. Lärarna har inte endast fătt möjlighet att korrigera och lägga till saker i samband med intervjuerna med de kognitiva kartorna och efter att ha läst sammanfattningarna. De har också haft möjlighet att göra detsamma i samband med gruppintervjun, eftersom de då kunnat ta del av kollegors redogörelser om det gemensamma temat. $\AA$ andra sidan finns en psykologisk aspekt att framhäva likheter om tematiken för att inte sticka ut för mycket som "olik" andra. Denna risk balanserades dock genom att de enskilda intervjuerna gjordes först och oberoende av varandra och att sammanfattningarna från dessa intervjuer låg till grund för gruppintervjun.

I tolkningsförfarandet har kartorna och sammanfattningarna gjort materialet överblickbart i syfte att kartlägga likheter och skillnader mellan vad lärarna har sagt om samhällskunskapsämnet och SO-undervisningen och identifiera mönster i denna kartläggning, medan utskrifterna och ljudupptagningarna använts för fördjupad granskning av giltigheten i de tolkningar som gjorts av kartläggningen och mönsteridentifieringen. Det är i samband med denna mönsteridentifiering som ämnesmarkörer, ämnesväxlingar och ämnesöverlappningar bildats för att kunna belysa samhällskunskapsämnets relationer till de andra SO-ämnena nedan.

\section{Resultat}

I samtalen med lärarna går det att se att geografi och historia dominerar SOgruppen genom sina strukturerande ämnesmarkörer och att dessa vanligtvis styr den undervisning som sker tillsammans med andra ämnen inom gruppen. Geografi är dock öppnare än historia och mycket av den gemensamma undervisningen sker mellan geografi, samhällskunskap och religionskunskap med utgångspunkt i geografi. Historieundervisningen sker mer sällan tillsammans med andra SO-ämnen men när det sker så sker det mestadels för att förtydliga 
kunskaper $i$ historia. Så är inte fallet när utgångspunkten är geografi. Då kompletterar oftast de andra ämnena geografiämnet. I båda fallen är historia och geografi huvudämnen där samhällskunskap och religionskunskap fungerar som biämnen styrda av de förras strukturerande ämnesmarkörer. De är ämnesmarkörer med en tydlig tyngdpunkt på strukturering av ämnenas stoff. Nelly beskriver dessa ämnen som ämnen med mycket "massa” som måste gås igenom och är svårt att hinna med (Intervju med Nelly våren 2010). I fallet med historia struktureras massan kronologiskt inom svensk dåtid medan geografi struktureras genom det vidgade rummets princip. Dessa struktureringar av ett späckat stoff ger också historia och geografi ett betydligt större utrymme inom SO-gruppen. Tage gör ett överslag om hur mycket tid han ägnar åt respektive ämne och uppskattar att hälften av tiden går åt till geografi, en fjärdedel till historia medan samhällskunskap och religionskunskap får dela på resten av tiden (Intervju med Tage våren 2010). Det är en skattning som stämmer relativt väl överens med de andra lärarnas fördelning (Gruppintervju våren 2010). Hur samhällskunskapsämnet interagerar med dessa två ämnen mer precist skall illustreras nedan för att visa hur dess underordnade roll och perifera position visavi dessa ämnen vidmakthålls och hur detta bidrar till att ämnets otydlighet som eget ämne kvarstår. När ämnet interagerar med religionskunskap sker det dock som likställt, men utan att skapa en grund för ökad tydlighet. Båda ämnena är för perifera och svaga som egna ämnen för att åstadkomma detta. Detta skall också illustreras nedan. Begreppen ämnesmarkörer, ämnesväxlingar och ämnesöverlappningar används för att skapa systematik i illustrationerna.

\section{Samhällskunskap förtydligar historia och ämnesöverlappning förhindras genom återväxling}

Nelly berättar att hon brukar undervisa kronologiskt i historia för det "är lättast" (Intervju med Nelly våren 2010). Hon startar vanligtvis med vikingatiden och avslutar med frihetstiden. Medeltiden utgör en period inom denna kronologi och när Nelly tar upp kungamakten under denna period säger hon så här i följande utbyte med intervjuaren:

Nelly: -Medeltiden och hur det såg ut i Sverige då, med kungen, om man tänker den här triangeln som vi pratade om för ett tag sedan, den här med präster, borgare och bönder.

Intervjuare: Det här med feodal...?

Nelly: Ja, precis och då är det ju också väldigt intressant att titta på liksom; -Hur ser det ut idag? -Vem är det som bestämmer idag? -Vad har kungen för makt idag? Och då kommer ju samhällskunskapen in. (Intervju med Nelly våren 2010)

Här syns hur Nellys beskrivning av undervisningen växlar över från historia till samhällskunskap. Det sker för att kontrastera kungens makt under medeltiden med den makt vår kung har idag. Dessutom ställs en fråga om vem som har 
liknande maktbefogenheter idag som kungamakten hade under medeltiden. I ämnesväxlingen görs det möjligt att lära sig något om nutida maktfrågor som en kunskap inom samhällskunskap men det huvudsakliga skälet till att växlingen sker är att göra det möjligt att lära sig vad som utmärker kungamakten historiskt sett. Ämnesväxlingen över till samhällskunskap sker i syfte att växla åter till historia, varför samhällskunskapsämnet fungerar som ett biämne som hjälper eleverna att bättre förstå en historisk företeelse. Detta hänger samman med samhällskunskapsämnets position till historia baserad på det senare ämnets relativa egenskaper i SO-gruppen och knutet till dess strukturerande ämnesmarkör.

Näst efter geografi beskrivs historia vara det mest etablerade ämnet med ett tydligt och ofta relativt omfattande innehåll som skall gås igenom, utifrån principen att starta vid en viss tidpunkt eller ett visst skede i förfluten tid och röra sig framåt mot en slutpunkt eller ett slutskede som också befinner sig i förfluten tid. Vi ser denna princip i redogörelsen om Nellys historieundervisning ovan. Principen har tidigare beskrivits i termer av "den kronologiskt framåtskridande dåtiden" och den utgör ämnets "strukturerande" ämnesmarkör (Kristiansson 2014, s. 227-228). Det är historia inom ramen för denna princip som skall förstås och som styr hur undervisningen relaterad till samhällskunskap läggs upp. Samhällskunskap som nutidsämne används för att undervisa om historia - om dåtiden i första hand och inte tvärtom, och det är därför som samhällskunskap fungerar som ett underordnat biämne med funktionen att bidra till ett förtydligande av ett historiskt innehåll inom historia som överordnat huvudämne. Detta gör att ämnesöverlappningar förhindras. Så länge ämnesintegrationen om företeelser som delas med andra ämnen sker för att göra den historiska aspekten av företeelsen begriplig, råder det inte heller någon oklarhet i vad de ingående ämnenas innehållsliga bidrag är. Denna "spärr" mot ämnesöverlappning föreligger inte i samhällskunskapsämnets relation till geografi, även om samhällskunskap också här fungerar som biämne och som kan härledas till geografis position inom SO-gruppen och dess strukturerande ämnesmarkör.

\section{Samhällskunskap kompletterar geografi och ämnesöverlappning öppnar för ämnesövertagande}

Tages beskrivning av geografi som basen i SO-undervisningen får inleda en redogörelse av samhällskunskapsämnets relation till geografi när de båda interagerar:

(N)är vi pratar SO-undervisningen så är det för min del i alla fall geografin som är basen som vi kanske jobbar med mest, men utifrån den då så blir ju också mycket samhällskunskap. Ja, demokrati och diktatur eller vad som helst. (Tage, gruppintervju våren 2010)

Att geografi utgör basen för SO-undervisningen delas av övriga lärare i studien och i citatet kan vi skönja hur samhällskunskap knyts till denna bas. Ett mer utförligt resonemang om hur detta tar sig uttryck syns i intervjun med Lars. I 
den redogör han för hur han tematiserar SO-undervisning i termer av "levnadsvillkor” där just geografi bildar bas utifrån en jämförelse mellan olika länder i vilket Sverige utgör en central jämförelsepunkt. Ofta tar han avstamp i naturgeografi och gör jämförelser mellan hur, för eleverna kända djurarter anpassar sig till olika levnadsvillkor som också syns i skiftande fysiska egenskaper hos arterna. Exempelvis skiljer sig en vanlig räv från en ökenräv och en fjällräv som en följd av att de över flera generationer anpassat sig till olika levnadsvillkor. Den naturgeografiska ingången följs vanligtvis av en övergång till en jämförelse av människors levnadsvillkor i olika delar av världen. Vanligt är då att utgå från olika försörjningsmöjligheter i Sverige som fiske och jordbruk för att sedan jämföra exempelvis jordbruket i dagens Sverige med jordbruk i utvecklingsländer. Återigen handlar jämförelsen om att visa hur olika levnadsvillkor leder till olika anpassning och liv, fortfarande inom ramen för geografi. Men så småningom sker en ämnesväxling till samhällskunskap genom att peka på vad det innebär att leva under olika styrelseskick. I slutet av intervjun prövar intervjuaren att sammanfatta Lars kognitiva karta för att se om han bekräftar den och har något att tillägga:

Intervjuare: Då är länder en del av geografin... man kan se liksom att nästa steg på något sätt är att knyta det till levnadsvillkor och då delar man upp det å ena sidan naturgeografiskt, som vetter mot djur och natur men som också människor är beroende av. Och sedan finns det en övergång till kultur och hur människor, befolkning och folkslag bor i olika länder och styrelseskick som man skulle kunna säga att det där är ju typisk samhällskunskap kanske men det finns en koppling till geografi?

Lars: Ja, det är det ju. (Intervju med Lars våren 2010)

Ämnesväxlingen i det här fallet, och som bekräftas av Lars (se 'Ja, det är det ju.' i citatet), sker för att behandla en aspekt av levnadsvillkor som inte ryms inom geografi som ändå utgör huvudämne för undervisningen om temat eftersom det i annat fall beskrivs höra hemma i geografi. Styrelseskick, och då framförallt jämförelsen mellan demokrati och diktatur, är något som huvudparten av de intervjuade lärarna placerar som ett tydligt kunskapsområde inom ett annars $\mathrm{i}$ många stycken otydligt samhällskunskapsämne. På så vis bidrar samhällskunskap innehållsligt med en för ämnet central del för att komplettera den annars geografidominerade undervisningen om levnadsvillkor. Ämnet fungerar inte som ett förtydligande av en geografisk företeelse utan som ett förtydligande av vad människors levnadsvillkor kan innebära som sträcker sig utanför geografi även om geografi fungerar som utgångspunkt och bas. Detta verkar ha att göra med den rumsliga grunden för jämförelsen som skiljer sig från den tidsliga jämförelsen som gjordes för att förtydliga kungamakt i förfluten tid i historia med hjälp av nutida makt inom samhällskunskap.

Geografins rumsliga grund befinner sig vanligtvis i nutid och bereder på så vis väg för en nutida jämförelse mellan olika styrelseskick i olika rum som en aspekt av levnadsvillkor och som hör hemma i samhällskunskap. Samhälls- 
kunskapsämnets biämnesfunktion visavi geografi antar härmed ett annat huvudmönster än ämnets funktion visavi historia, och som delas av de flesta lärarna i studien. Det kompletterar geografiämnets belysning av levnadsvillkor med ett eget kunskapsområde och får således ett egenvärde bortom geografi på ett annat sätt än när det förtydligar företeelser som ryms inom historia. Förutsättningen är dock att kompletteringen, i det här fallet jämförelsen mellan olika länders styrelseskick som en jämförelse mellan demokrati och diktatur, ses som ett område som tillhör samhällskunskap. Denna förutsättning gäller dock inte för alla lärare i studien. Några glider i frågan, exempelvis Emmy:

Det mesta i SO:n som jag jobbar med så är det ju geografin. Där vi har gjort olika resor och sånt där, tagit upp konflikter som har varit i de länderna och diskuterat demokrati. (Intervju med Emmy våren 2010)

Jämfört med citatet från Tage ovan saknas kopplingen till samhällskunskap i detta citat. Vad Emmy berättar är att man studerat diktaturer (se 'de länderna' i citatet) och då diskuterat demokrati $i$ geografi. Hur detta kan komma sig kan, likt samhällskunskapsämnets relation till historia ovan, problematiseras som ett utfall av samhällskunskapsämnets position inom SO-gruppen.

Genom geografiämnets rumsliga jämförelser i ett ofta nutida sammanhang får alltså samhällskunskap vid ämnesväxlingar ett egenvärde när det relateras till geografi genom att det lyfter en aspekt av människors levnadsvillkor som är centralt inom samhällskunskap, dvs. styrelseskick och jämförelsen mellan diktatur och demokrati. Detta sker emellertid utifrån positioner i SO-gruppen där geografi är ett centralt huvudämne och samhällskunskap ett perifert biämne. Likaväl som samhällskunskap kan "komma till sin rätt” i denna relation kan det också försvinna. Det senare sker när det blir oklart vad som är ett samhällskunskapsinnehåll i sammanhanget och som kan förmodas ligga bakom det ämnesövertagande som Emmy ger uttryck för ovan. Ämnesväxlingen har uteblivit genom denna oklarhet och en överlappning har av allt att döma skett, måhända stegvis, där geografiämnets dominans till slut inkorporerat styrelseskick, diktatur och demokrati som ett geografiinnehåll. Nyckeln tycks vara den rumsliga nutida jämförelsen. För något liknande går inte att se när samhällskunskapsämnet interagerar med historia i samtalen med lärarna. Här har det visat sig att den tidsliga relationen där samhällets nutid skall förtydliga företeelser i historiens dåtid tycks fungera som en spärr mot ämnesövertagande, även om samhällskunskap inte ges samma egenvärde som när ämnesväxlingen rörande levnadsvillkor sker vid interaktion med geografi. I båda fallen utgör samhällskunskap biämne som förtydligar historia respektive kompletterar geografi, något som inte är fallet när ämnet interagerar med religionskunskap. 


\section{Samhällskunskap bidrar likvärdigt vid ämnesväxling med religions- kunskap och ämnesöverlappning öppnar för nya "ämnen”}

"Lag och rätt” utgör ett gemensamt område för samhällskunskap och religionskunskap när ämnesväxling sker mellan ämnena:

Lag och rätt här det handlar ju en hel del om religion. (...) (R)eligionen finns med som en betydande del där i olika grad ... när det gäller olika kulturer, olika länder, olika världsdelar, vilken påverkan den har och då har den ju varit med att påverka även synen på lag och rätt då. (...) Men lag och rätt i den bemärkelsen som vi behandlar... pratar vi ofta om som en del i ett arbete i samhällskunskapen där man jobbar med lag och rätt och då jobbar man ju med lag och rätt i Sverige då. (Intervju med Lars våren 2010)

Även om det inte blir tydligt hur de båda ämnena mer exakt bidrar innehållsligt till lag och rätt, visar utsagan från Lars på en tydlig ämnesväxling mellan religionskunskap och samhällskunskap där inget av ämnena är överordnat det andra. Lag och rätt som tema kommer i förgrunden uppbackad av ett innehåll med en likställd arbetsfördelning mellan de båda ämnena. Samtidigt visar samtalen att båda ämnena intar en mer perifer position i förhållande till geografi och historia i SO-gruppen. Denna position tycks medföra att också interaktionen mellan dessa ämnen, när de behandlar ett gemensamt innehåll, sker utan att något av ämnena är överordnat det andra och intar funktionen som huvudämne såsom är fallet när samhällskunskap interagerar med historia och geografi. Inte heller går det att identifiera något ämnesövertagande när ämnesöverlappningar sker mellan ämnena, trots att det då kan röra sig om ett mer perifert innehåll i samhällskunskap som exempelvis etik. Detta kan synliggöras i intervjun med Tage när intervjuaren försöker få en överblick över den kognitiva kartans innehåll. Angående religion som en uttalad del av kartan säger då Tage att...

... etikprat kan ju komma in precis när som helst. Det kan vara saker som händer på rasterna. Diskussioner kring det.

Varpå följande utbyte sker:

Intervjuare: Är det vanligt...

Tage: Ja, livsfrågor och så vidare och så vidare.

Intervjuare: Så ett vanligt exempel när det gäller etikprat är att utgå från sånt som händer i vardagen?

Tage: Ja, det törs jag nog påstå ja. Eller att det dyker upp något på veckans nyheter.

Intervjuare: Om den typen av frågor kommer upp?

Tage: Ja, precis. Det täcker ju så stort.

Intervjuare: För du har placerat in etik inom religion men du har ändå etik där också (pekar på samhällskunskap och demokrati, författarens förtydligande)? 
Tage: Ja, alltså det är ju tätt sammanbundet. (Intervju med Tage våren 2010)

Etik blir ett område som överlappar samhällskunskap och religionskunskap och som också syns i samtalen med andra lärare i studien. Emellertid sker inget ämnesövertagande utan otydligheten kvarstår. Detta tycks kunna relateras till båda ämnenas perifera position inom SO-gruppen och likvärdiga position visavi varandra också när innehållsbidragen är otydliga. Istället för att något av ämnet tar över det "omtvistade" innehållet såsom geografi gör ovan i fallet med Emmy kan ett nytt "ämne" skönjas i citatet ovan. Tage talar om livsfrågor utifrån sådant som händer i vardagen. På annat håll i samtalen talas det om en vardagsnära livskunskap. Tänkbart är här att detta nya "ämne” kan skönjas som ett resultat av de båda ämnenas perifera position i SO-gruppen.

\section{Konklusion och diskussion}

Att studera samhällskunskapsämnet relationellt visavi övriga SO-ämnen på mellanstadiet och som illustrerats ovan gör det möjligt att se vad som utmärker ämnet i ett annat ljus än om det endast skulle studeras enskilt. Ämnet har, likt ämnet högre upp i skolsystemet, ett etablerat och återkommande innehåll men ses i vid mening som stort, gränslöst, osammanhängande och föränderligt. Och det är ett ämne som tycks bygga en betydande del av sitt existensberättigande på att gå in i andra SO-ämnen. När detta sker så sker det mestadels som ett underordnat biämne visavi de två ämnen som tar mest plats och har de centrala positionerna inom gruppen, dvs. geografi och historia. Som underordnat och perifert blir det inte mycket tid över att utveckla ämnets egna etablerade kunskapsområden, att göra dem mer sammanhängande inåt och utåt med tydligare yttre gränser visavi andra skolämnen. Ämnets likvärdiga relation till religionskunskapsämnet äger föga potential att förändra detta tillstånd eftersom religionskunskap är lika perifert som samhällskunskap.

Samtidigt går det att argumentera för att det inte är ämnets relation till historia och geografi $i$ sig som låser fast det vid dess otydlighet. Illustrationen ovan om interaktionen med historia visar en ämnesväxling som har potential att förtydliga och nyansera politisk makt, ett centralt begrepp inom samhällskunskap. Interaktionen med geografi visar på en liknande potential att utveckla förståelsen av statsskick, demokrati och diktatur. Genom interaktion med systerämnena finns således en potential att utveckla tydligheten i samhällskunskapsämnet som ett eget ämne. Problemet är dock att denna utvecklingspotential av allt att döma hindras av de strukturerande ämnesmarkörer som etablerats för historie- och geografiämnet. De bygger på att pressa samman ett stoffspäckat och förstelnat innehåll som måste "hinnas med", och som inte tycks vara en svensk företeelse utan som syns på många andra håll i de yngre skolårens SOundervisning. I USA har forskare använd epitetet "a mile-wide and an inch-deep 
curriculum” för att peka på denna problematik (se exempelvis Brophy \& Alleman, 2009). I Sverige talar man ibland om selektiva traditioner (se exempelvis Englund, 1986; Molin, 2006). I vår forskargrupp inom CSD har vi sett liknande mönster (Bladh, 2014; Kristiansson, 2014; Stolare, 2017). Också historia och geografi, sin dominans till trots, tycks således vara i behov av förändring från ytlig stoffbredd till mer begreppsligt djup för att göra skillnad hos elevers förståelse och hantering av det sociala livet. En viktig slutsats jag drar av min studie är således att det finns en potential genom interaktionen mellan SO-ämnena att utveckla samtliga ämnen som egna ämnen. I förlängningen kan denna utveckling också gå åt andra hållet så att interaktionen mellan ämnena ger en mer sammanhängande orientering av vårt samhälles karaktär och uppbyggnad i tid och rum. Med detta efterlyses mer ämnesdidaktisk forskning som beaktar relationer mellan ämnen, exempelvis genom att närma sig det forskningsområde som går under namnet "interdisciplinär-", eller "ämnesintegrerad" forskning. Blanck (2014) har visat det fruktbara i ett sådant närmande genom att peka på betydelsen av såväl ämnesuppdelad som ämnesintegrerat SO-undervisning för att i olika faser bygga en förståelse av samhällsfenomen som pengar, staden och hållbar utveckling. Vår forskargrupp håller på att arbeta utifrån en liknande ansats genom att studera hur SO-ämnena enskilt och tillsammans kan bidra till att förstå och hantera nutida samhällsfrågor på ett kraftfullt sätt. Frågor som migration och hållbar utveckling tror vi kan bli mer begripliga om de belyses både uppdelat och integrerat inom SO-gruppen (Stolare, 2016). Men för att denna belysning skall bli kraftfull tror vi också att de roller, positioner och kännetecken som illustrerats ovan behöver förändras så att varje ämne kan bidra på ett kraftfullt sätt. Ett stort, gränslöst, osammanhängande och föränderligt samhällskunskapsämne som intar en underordnad roll i interaktionen med andra SO-ämnen och lever en undanskymd tillvaro i SO-gruppen, har svårt att ge ett sådant bidrag.

Avslutningsvis vill jag peka på behovet av nya nedslag på svenskt mellanstadium för att studera samhällskunskapsämnet och undervisningen i det. Mycket tyder på att kontexten inom mellanstadiet håller på att förändras i riktning mot en starkare ämnesbunden kontext. Betygssättning av ämnesbehöriga lärare utifrån en mer ämnesbunden kursplan tycks bidra till denna förändring där klasslärarsystemet håller på att brytas upp och ersättas alltmer av vad som kan kallas ett "ämnesgruppsystem”. Det har blivit allt vanligare att samma klass möter två lärare istället för en för att lära sig saker i matematik och i de naturorienterande ämnena, respektive svenska och SO-ämnena. Jag har också mött flera signaler om att framförallt avsaknaden av etiketterande ämnesmarkörer för samhällskunskap på mellanstadiet håller på att förändras. Idag hör jag lärare säga att de talar om ämnet, att det skrivs in i schemat och på tavlan och att man har egna böcker, prov och läxor i det. Förändringar i mellanstadiekontexten tycks leda till förändring av samhällskunskapsämnets tydlighet. 


\section{Referenser}

Adler, M. \& Flihan, S. (1997). The interdisciplinary continuum: Reconciling theory and practice. Albany: National Research Center on English Learning \& Achievement.

Bernmark-Ottosson, A. (2009). Samhällskunskapslärare. I B. Schüllerqvist \& C. Osbeck (red.), Ämnesdidaktiska insikter och strategier (s. 9-32). Karlstad: Karlstad university press.

Bladh, G. (2014). Geografilärare och geografiundervisning i den svenska grundskolan: Några delresultat av en enkätstudie. Geografiska notiser, 4, 158-168.

Blanck, S. (2014). När ämnen möts: En analys av samhällskunskapsämnets funktioner och karaktär vid ämnesintegrerad undervisning. Karlstad: Karlstad university studies.

Brophy, D. \& Alleman, J. (2009). Meaningful social studies for elementary students. Teachers and Teaching: Theory and Practice, 15(3), 357-376.

Bryman, A. (2011). Samhällsvetenskapliga metoder. Malmö: Liber.

Børhaug, K., Hunnes, O. R. \& Samnøy, S. Å. (2015). Spadestikk i samfunnsfagdidaktikken. Bergen: Fagbokforlaget.

Christensen, T. S. (2011). Samfundsfag: et senmoderne fag? Nordidactica: Journal of Humanities and Social Science Education, 1, 1-25.

Christensen, T. S. (red.) (2015). Fagdidaktik i samfundsfag. Frederiksberg: Frydenlund.

Christensen, T. S. \& Hobel, P. (2014). Interdisciplinaritet - en udfordring til fagdidaktikken. Nordidactica: Journal of Humanities and Social Science Education, 1, i-xiv.

Englund, T. (1986). Samhällsorientering och medborgarskapsfostran i svensk skola under 1900-talet. Uppsala: Uppsala universitet.

Forsberg, E. \& Lindberg, V. (2010). Svensk forskning om bedömning: en kartläggning. Stockholm: Vetenskapsrådet.

Imsen, G. (1999). Lärarens värld: Introduktion till allmän didaktik. Lund: Studentlitteratur.

Khattri, N. \& Miles, M. B. (1995). Thinking about restructuring: The maps in our Minds. New York: NCREST, Columbia university.

Klausen, S. H. (2011). På tværs af fag. I S. H. Klausen (red.), På tværs af fag: Faglig samspil i undervisning, forskning og temaarbejde (s. 11-30). København: Akademisk forlag.

Klein, J. T. (2010). A taxonomy of interdisciplinarity. I R. Frodeman (red.), The Oxford handbook of interdisciplinarity (s. 15-30). Oxford: Oxford university press.

Koritzinsky, T. (2014). Samfunnskunnskap: fagdidaktisk innføring. Oslo: Universitetsforlaget.

Kristiansson, M. (2014). Samhällskunskapsämnet och dess ämnesmarkörer på svenskt mellanstadium - ett osynligt eget ämne som bistår andra ämnen. Nordidactica: Journal of Humanities and Social Science Education, 1, 212-233.

Krogh, E. \& Nielsen F. (red.) (2011). Sammenlignende fagdidaktik. Århus: Århus universitet.

Krogh, E. \& Nielsen F. (red.) (2012). Sammenlignende fagdidaktik 2. Århus: Århus universitet.

Kvale, S. \& Brinkmann, S. (2009). Den kvalitativa forskningsintervjun. Lund: Studentlitteratur.

Linn, R. (2000). Assessment and accountability. Educational Researcher, 29 (2), 4-16.

Molin, L. (2006). Rum, frirum och moral: en studie av skolgeografins innehållsval. Uppsala: Uppsala universitet.

Odenstad, C. (2011). Prov och bedömning i samhällskunskap: En analys av gymnasielärares skriftliga prov. Karlstad: Karlstad university studies.

Olsson, R. (2016). Samhällskunskap som ämnesförståelse och undervisningsämne: Prioriteringar och nyhetsanvändning hos fyra gymnasielärare. Karlstad: Karlstad university press. 
Regeringens proposition 2008/09:66. En ny betygsskala. Stockholm:

Utbildningsdepartementet.

Regeringens proposition 2008/09:87. Tydligare mål och kunskapskrav - nya läroplaner för skolan. Stockholm: Utbildningsdepartementet.

Sadovnik, A. R. (1995). Basil Bernstein's theory of pedagogic practice. I A. R. Sadovnik (red.), Knowledge and pedagogy: the sociology of Basil Bernstein (s. 3-35). London: Ablex publishing.

Schüllerqvist, B. (2009). Ämnesdidaktisk lärarforskning: ett angeläget forskningsfält. I B. Schüllerqvist \& C. Osbeck (red.), Ämnesdidaktiska insikter och strategier (s. 9-32). Karlstad: Karlstad university press.

Schüllerqvist, B. (2010). CSDs forskningsprogram 2010-2012. Karlstad: CSDs hemsida http://www.kau.se/sites/default/files/Dokument/subpage/2009/12/csd_fo_program_5_pdf 78462.pdf

Schüllerqvist, B. (2012). De samhällsvetenskapliga ämnenas didaktik: en skandinavisk översikt. I N. Gericke \& B. Schüllerqvist (red.), Ämnesdidaktisk komparation: Länder, ämnen, teorier, metoder, frågor och resultat (s. 25-43). Karlstad: Karlstad university press.

Schüllerqvist, B. \& Osbeck, C. (2009). Lärarnas ämnesdidaktiska insikter och strategier. I B. Schüllerqvist \& C. Osbeck (red.), Ämnesdidaktiska insikter och strategier (s. 205-230). Karlstad: Karlstad university press.

Sjøberg, S. (2014). PISA-syndromet - Hvordan norsk skolepolitikk blir styrt av OECD. Nytt norsk tidsskrift, 31(1), 30-43.

Skollagen 2010:800. Bilaga 1: Timplan för grundskolan. Stockholm: Utbildningsdepartementet.

Skolverket (2010). Rustad att möta framtiden? PISA 2009 om 15-åringars läsförståelse och kunskaper i matematik och naturvetenskap. Stockholm: Skolverket.

Skolverket (2011). Lgr 11. Läroplan för grundskolan, förskoleklassen och fritidshemmet 2011. Stockholm: Skolverket.

Skolverket (2013). PISA 2012: 15-åringars kunskaper i matematik, läsförståelse och naturvetenskap. Stockholm: Skolverket.

Stolare, M. (2016). Forskningsprogram 2016-2018, Centrum för de samhällsvetenskapliga ämnenas didaktik, Karlstads universitet. Karlstad: CSDs hemsida https://www.kau.se/sites/default/files/Dokument/subpage/2009/11/forskningsprogramfinal _pdf_11559.pdf

Stolare, M. (2017). Did the Vikings really have helmets with horns? Sources and narrative content in Swedish upper primary school history teaching. Education 3-13: International Journal of Primary, Elementary and Early Years Education, 45(1), 36-50.

Vernersson, F. (1999). Undervisa om samhället: Didaktiska modeller och läraruppfattningar. Lund: Studentlitteratur. 